\title{
Sundanese Culture Local Wisdom Based Leadership: The Dynamics of Government Leadership of Purwakarta Regent Period 2008-2018
}

\author{
Ednawan Prihana ${ }^{1}$, Ngadisah $^{2}$, Muhadam Labolo ${ }^{3}$, Kusworo ${ }^{4}$ \\ Institut Pemerintahan Dalam Negeri (IPDN), Indonesia \\ Email: ednawan.prihana@gmail.com
}

\begin{abstract}
This study aims to analyze the dynamics of local government leadership based on the wisdom of Sundanese culture in Purwakarta Regency in the period 2008-2018. This study uses a qualitative research design, research data collection techniques using documentation studies, interviews and observations. The results of this study found that the leadership of the Purwakarta Regent in the period 2008-2018 based on Sundanese culture local wisdom with the concept of Sunda Dasa Prasanta's leadership could be accepted and supported by the majority of the people of Purwakarta Regency. In his leadership, there are dynamics that cause polemics and pros and cons in the community, but the dynamics that arise can be resolved properly by communicating and holding communication forums. The "Sundanese Style Harmony" leadership model is an ideal formula as an alternative to the existing leadership model that emphasizes harmony and balance between Sundanese Religion and Culture, where the position of Religion and Culture is balanced, none are relatively higher or lower.
\end{abstract}

Keywords: leadership, government, local wisdom, Sundanese culture.

\section{A. INTRODUCTION}

Purwakarta Regency shows an interesting development, at least for the last ten years. Purwakarta does something unusual in the context of leadership, bureaucracy and development policy. The District Head of Purwakarta built his area using a government leadership approach that was different from other regions. This is a new breakthrough and what has been done in Purwakarta has not been done much by other Regional Heads in Indonesia.

Ten years ago Purwakarta was only a district that was not underestimated, but now through the breakthroughs made by the Purwakarta Regent in the period 20082018, the city is better known both nationally and even internationally. Even more interesting and unique is that the Regent of Purwakarta operates the values of the local area namely Sundanese cultural values that are applied in every aspect of government in Purwakarta Regency (Mulyani, \& Ratnapuri, 2018; Heryana, 2014; Anwar \& Hendrawan, 2020).

The Regent of Purwakarta in the period 2008-2018 tried to build a mindset of Purwakarta citizens to love local wisdom more, preserve Sundanese culture by carrying 
out development that prioritizes Sundanese cultural values. Sundanese cultural ancestral values are used as a spirit to build the City of Purwakarta and as a fundamental spirit of the community, many policies made by the Purwakarta Regent in the period 2008-2018 were issued departing from the typical domain of Sundanese culture (Haddad, et al., 2017). This is a manifestation of the implementation of Law No. 23 of 2014 concerning Regional Government as a constitutional effort to encourage improvement in the performance of regional government through regional innovation.

Purwakarta Regent Government Leadership period 2008-2018 based on local wisdom Sundanese culture fruited various successes, one of which is an award from the Corruption Eradication Commission (KPK) which has awarded Purwakarta Regency as the best region in the management of LHKPN 2016. As Regent, Dedi Mulyadi also invited by the United Nations (UN) in July 2016 with the theme of the Moral Leadership of Sundanese Culture-Based Vision. The Sukarno Center in July 2016 also awarded Regent Dedi Mulyadi as the Exemplary Leader of Democracy. He also won awards as the Head of Innovative Regions in 2015 and 2016 from MNC Group (Jamaludin, 2019; Febriantin, 2016).

Various successes have been achieved, making the Purwakarta Regency Government get various awards both internationally, nationally and provincially. But in the leadership of the Purwakarta Regent's government, it cannot be separated from the various dynamics and polemics that arise in the community. Therefore, the purpose of this study is to analyze the dynamics of local government leadership based on the wisdom of Sundanese culture in Purwakarta Regency in the period 2008-2018.

There have been many studies on leadership based on local wisdom (Elfira, 2013; Hudaya \& Nugroho, 2013; Suyono, 2016; Febriantin, 2017; Muslim, 2019; Jamaludin, 2019; rahmat et al., 2013). However, research that specifically examines leadership based on local wisdom of Sundanese culture has not been conducted by other researchers, therefore this research is research that contains elements of novelty and has an impact on scientific development.

\section{B. MethoD}

This study uses a qualitative research design, where this qualitative approach looks at the process from one event to another comprehensively (Adi, 2004; Moleong, 2017; Creswell, 2017; Sugiyono, 2017). This research data collection technique uses documentation studies, in-depth interviews, and observations. In this study, researchers will conduct data analysis through a cycle process using a data analysis process model according to Irawan (2006), which consists of seven activities namely raw data collection, data transcripts, coding, data categorization, temporary inference, triangulation, and final inference. 


\section{RESUlt AND Discussion}

The Regent of Purwakarta for the period of 2008-2018 raised many ideas, ideas, and actions. If observed everything can be drawn on one thing, namely the spirit to build a cultured Purwakarta for the realization of a government that is able to prosper its people. Prosperous is not only outwardly but also richly inwardly, Building is not only the origin of the building but by continuing to prioritize human beings to land entities, water entities, air entities, and sun entities.

The strength of the cultural spirit is the basis for implementing the Purwakarta Regent Leadership for the Period of 2008-2018, the Regent sees that now there is a disruption of development and humanity in the social reality of the community. Speaking of nature, there are four basic foundations of nature, these natural foundations as pillars or cultural foundations. These four things are land, water, wind, and sun. Humans should unite with the four foundations during life in the world. Cultured creatures are those who have been able to unite with soil, water, wind, sun (Mulyadi, 2015).

The Regent of Purwakarta for the period of 2008-2018 continued to build a Sundanese identity in the City of Purwakarta because he felt that the Sundanese people were beginning to lose their delay. Later identity has implications for food, clothing and so on. After that, the implications will realize the tradition without eliminating modernity. Traditions must be built in the modern world order in order to compete with other regions. A true leader must develop spirit, taste or spirit. For the Regent of Purwakarta, the period of 2008-2018, the spirit of building a culture based was not at odds with religious excitement (Mulyadi, 2015).

Various elements of society in the city of Purwakarta such as community leaders, religious leaders, youth, media, historians, and various other elements have a good view and support the local wisdom leadership of Sundanese Culture from the Regent of Purwakarta in the period 2008-2018. From various public opinions, it can be concluded that the leadership of Sundanese culture local wisdom from the Regent of Purwakarta in the period 2008-2018 can be accepted by the people of Purwakarta Regency, this is because the majority of the community supports the leadership of the regent and even the regent can be elected in the second period of his leadership, this shows a parameter that his leadership is desired by the majority of Purwakarta people.

But in the leadership of the Purwakarta Regent's government, it did not fit the dynamics and polemics that arose in the community. The arrangement of the city in Purwakarta today is indeed very changing because the Regent of Purwakarta wants to restore the ancestral culture that was almost lost due to changing times. But new problems have arisen in some communities because after seeing and observing the changes that occur in the city in Purwakarta more like Balinese culture. For example, there are statues of puppet figures in almost every crossroad, tourist attractions and city parks, erection of gates in every alley, the shape of a government office fence and public facilities, trees in the city and in the local government office bound by a striped patterned 
cloth yellow, are Sundanese and Balinese culture the same? That is what is in the minds of some Purwakarta people, but no one dares to voice their opinions or questions, the community finally just follows what the Purwakarta city government is doing.

The Regent of Purwakarta in the 2008-2018 period issued policies that caused controversy and dynamics in his leadership, one example was the ideological policy which was considered by some to be in contradiction with routine habits in the community, the goal being that Sundanese culture would continue to live in its own village. So far there is no symbolic formula about the character of the region that reflects culture. The ideological policy was realized in the regional development policy with Sundanese values in its leadership. The Sundanese values are outlined in the slogan "Spirit Culture".

Spirit of Culture is defined as the spirit and movement to build the Sundanese tinsel which is expected to have competitiveness for other nations in the world. This Cultural Spirit is applied in every aspect of government in Purwakarta Regency both in terms of health, education, and development. This Spirit of Culture is also used as a tool or a way to achieve the goals to be achieved from the leadership of Purwakarta Regent in the period 2008-2018. Implementation of this Cultural Spirit by the construction of statues in the city of Purwakarta. An example is the statue of Pandawa Lima which symbolizes the values of cultural wisdom about humans symbolized by the five puppets. This kind of ideological policy is rarely found in government leadership in other parts of Indonesia.

Another unique policy that has caused controversy regarding Spirit Culture is that residents are asked to decorate their area of residence with seven kinds of accessories made of bamboo, such as cetok (hat), boboko (rice basket), hihid (fan), aseupan (were to cook rice), nyiru, kentongan and beas parelek, the aim is to make local wisdom globalized.

The policy of making archways and lights uniformly also led to dynamics in his leadership, because the material to build a uniform gate and made of woven bamboo and wood that had been formed into cooking utensils, one of which was "Boboko" a place of rice which was made an icon of "Purwakarta Character".

Purwakarta Character is described in the missions as follows:

1. Developing development based on religion and local wisdom oriented to the excellence of education, health, agriculture, industry, trade, and services.

2. Develop regional infrastructure based on the values of local wisdom and oriented to the spirit of changing global competition.

3. Increasing the integrity of the environment both upstream and downstream, physical and social.

4. Develop an effective government structure oriented to the satisfaction of public services, develop the entrepreneurial potential of the people-oriented bureaucracy. 
Having character here means that the Regent of Purwakarta for the period of 2008-2018 wants that the Purwakarta people have the character and character of delays that have long been eroded by changing times and want to restore the identity of the values of delay in society.

The Regent of Purwakarta in the period 2008-2018 always wore clothing in his nose that was unique and different from other regional leaders, everyday wearing distinctive black Sundanese clothes that read "Dangiang Ki Sunda" and a headband. If the dry season, the clothes worn are white, while in the rainy season the clothes worn are black. All the clothes are formulated based on needs, the tie means mirror with the philosophy of cingcarincing pageuh kancing sing saringset pageuh iket which means that humans start from the cleanliness of the heart, and cleanliness of the heart gives birth solemnly in prayer. While clothes are a sign of culture, because the environment is in the countryside it must go to the fields, to the garden, to the forest, the need for clothes must be loose because of high levels of sweat, pants on the heels so as not to be stepped on and take steps quickly.

Another unique policy that has caused controversy is the Regent's Regulation Number 69 the Year 2015 regarding Character Education. This Regent Regulation was formed with the aim of forming a generation of children of the nation who are intelligent, skilled, love the country and the region, independent, able to adapt to their environment, with wide scope and noble character. The issuance of the regent's regulation has an impact on changes in the existing education system starting from the time of school entry were for rural areas entering from 06:30 to 10:30 while for urban areas starting at 07.00-15.00.

In addition, there were also changes in school uniforms as stipulated in the regent's regulations which removed the original school uniforms replaced with scout clothes on Monday, Sundanese traditional clothes on Tuesday and Wednesday, batik clothes on Thursday and Muslim clothing on Friday. Furthermore, the regent's regulations govern the obligation to bring food/drink to school and eliminate canteens in the school environment.

Typical policies that cause other controversies such as building Sundanese figures in every corner of Purwakarta Regency, the application of black and white cloth in every building in Purwakarta Regency, some people consider the use of local wisdom values of Sundanese culture has come out of the teachings of Islam and the community considers the existence of Hinduism in Purwakarta Regency. Even some people considered that the development carried out seemed forced and not in accordance with the scale of the priority needs of the community, which eventually resulted in rejection from the community regarding the leadership and policies of the Purwakarta Regent in the period 2008-2018.

Another problem is that in the leadership of Purwakarta Regent in the period 2008-2018, his policy caused a lot of controversy in the community such as turning off 
the lights during the full moon, requiring students to make wealth reports, requiring the State Civil Apparatus (ASN) to use bags made of burlap sacks and wisdom others are less common and sometimes cause controversy. The pro considers that the policy is a good form of breakthrough that can help the running of the Purwakarta Regency government. On the other hand, the counterparties say that these specific policies are not yet time or are not appropriate to be applied in Purwakarta Regency because Purwakarta Regency itself is the second smallest regency in West Java.

The success of the leadership of the Purwakarta Regent Government in the period 2008-2018 was inseparable from several supporting factors. Supporting factors include the Purwakarta community, which largely supports the leadership of the regent because the regent understands public desires, the regent's concern for his people and Sundanese culture Purwakarta people and the regent himself loves and understands the Sundanese culture. In addition to the supporting factors of the Purwakarta Regent's leadership for the period of 2008-2018, there were also factors that hampered him. The findings from the research results, the factors that hampered the leadership of Purwakarta Regent in the period 2008-2018 were differences in the mindset that existed in some communities, communication, and human resource competencies.

In the leadership of Purwakarta regent in the period 2008-2018, there were pros and cons in the community and caused dynamics, this was due to an imbalance between the portion of cultural and religious factors. Cultural factors are higher in position than cultural factors. Some people consider the district head to favor and prioritize local culture and wisdom compared to religion. Religion is seen by some people as being overridden, giving rise to social jealousy for those who prioritize religion. Desires and needs of religious groups are felt to be less accommodated by the regent and feel childish, giving rise to negative perceptions and mindset regarding the regent's policies, especially those relating to the construction of statues in the city of Purwakarta that are considered to violate Islamic religious law, causing turmoil and dynamics in society.

On the other hand, the opposing group said that the regent was more focused and prioritized policies related to local wisdom and Sundanese culture. Lots of local wisdom policies of Sundanese culture have been implemented in the community such as Purwakarta Character with its Spiritual Power. Character Education, Purwakarta Specialties and development of city identity and attributes.

The communication made by the district head to elements of the community was felt to be limited and not yet maximal, especially to groups opposing his policy. Coordination in the implementation of policies that are sensitive enough to be applied by the community does not involve these groups, so they feel they are not spoken to and abandoned, even though they are also part of the community elements in Purwakarta. 


\section{CONCLUSION}

Purwakarta Regent Government Leadership Period 2008-2018 based on local wisdom Sundanese cultural background because of the Regent's love of Sundanese cultural traditions, with the aim of preserving the cultural heritage of the ancestors so as not to be eroded by time. The leadership based on local wisdom of Sundanese culture with the Dasa Prasanta concept can be accepted and supported by the majority of the people of Purwakarta Regency, despite the dynamics that cause polemics and pros and cons in the community. However, this dynamic can be resolved well by communicating and holding communication forums.

The supporting factor for the Purwakarta Regent's leadership in the 2008-2018 period was culture, the regent's personal personality in his leadership loved and mastered the concept of Sundanese leadership and understood the needs of the Purwakarta community in terms of accelerating the development process. While the inhibiting factors of leadership are less effective communication factors, differences in mindset and the low quality of human resources. The "Sundanese Style Harmony" leadership model is an ideal formula as an alternative to the existing leadership model that emphasizes harmony and balance between Sundanese Religion and Culture, where Sundanese Religion and Culture are balanced, none are relatively higher or lower.

\section{REFERENCES}

1. Adi, R. (2004). Metodologi Penelitian Sosial \& Hukum.Jakarta: Granit.

2. Anwar, A. A., \& Hendrawan, J. H. (2020). Ethnopedagogy: Sundanese Leadership Values. Jurnal Ilmu Kesejahteraan Sosial HUMANITAS, 1(2), 128-140.

3. Creswell, J. W. (2017). Research Design: Pendekatan Metode Kualitatif, Kuantitatif dan Campuran. Yogyakarta: Pustaka Pelajar.

4. Elfira, M. (2013). Model Kepemimpinan Berbasis Kearifan Lokal di Minangkabau dan Bugis. Paper. Unpublished.

5. Febriantin, K. (2016). Faktor Pemimpin dan Kepemimpinan dalam Tata Kelola Pemerintahan di Kabupaten Purwakarta Periode Tahun 2008-2015. Jurnal Politikom Indonesiana, 1(2), 43-58.

6. Haddad, R., Mochamad, S., \& Hijran, M. (2017). Model Kepemimpinan Politik Sunda dalam Konteks Pendidikan Politik. Prosiding Konferensi Nasional Kewarganegaraan III p-ISSN 2598-5973 11 November 2017, Universitas Ahmad Dahlan, Yogyakarta.

7. Heryana, A. (2014). Jejak Kepemimpinan Orang Sunda: Pemaknaan Ajaran dalam Naskah Carita Parahyangan (1580). Patanjala, 6(2), 163-178.

8. Hudaya, Z. A., \& Nugroho, S. W. (2013). Kearifan lokal budaya Jawa sebagai basis model kepemimpinan yang efektif. Sustainable Competitive Advantage (SCA), 3(1).

9. Irawan, P. (2006). Penelitian Kualitatif dan Kuantitatif Untuk Ilmu-Ilmu Sosial. Jakarta: DIA FISIP UI. 
10. Jamaludin, A. N. (2019). Model Kepemimpinan Sunda Jawa Barat. Jurnal Kelola: Jurnal Ilmu Sosial, 2(1), 34-61.

11. Moleong, L. J. (2007). Metode Penelitian Kualitatif. Bandung: Remaja Rosdakarya.

12. Mulyadi, D. (2015). Spirit Budaya Kang Dedi. Jakarta: Gramedia Printing Group.

13. Mulyani, M., \& Ratnapuri, C. I. (2018). Nilai-Nilai Kepemimpinan Sunda: Definisi dan Model Konseptual. Jurnal Manajemen dan Bisnis Indonesia, 5(3), 327-345.

14. Muslim, M. A. (2019). Kapabilitas Dinamis Dalam Kepemimpinan: Studi Atas Kepemimpinan Bupati Purwakarta Dedi Mulyadi. Decision: Jurnal Administrasi Publik, 1(01), 1-18.

15. Rahmat, K., Cristiana, D. M., Lukman, F., \& Gunardi, G. (2013). The Implementation of Sundanese Leadership Values in Education Management: A Study on" DasaPasanta" in School Principal Leadership Based on Sundanese Cultural Values of Leadership. International Journal of Education, 5(4), 110.

16. Sugiyono. (2013). Metode Penelitian Kuantitatif Kualitatif dan RED. Bandung: Alfabeta.

17. Suyono, J. (2016). Hasthabrata: Menggali Kembali Kepemimpinan Dengan Kearifan Lokal (Sebuah Pendekatan Mix Method Di Solo Raya) (Doctoral dissertation, Universitas Brawijaya). 